\title{
PROFIL KECAKAPAN SOSIAL DAN PERSONAL SISWA DALAM HUBUNGANNYA DENGAN KECAKAPAN AKADEMIK PADA PEMBELAJARAN KIMIA
}

\author{
Latisma Dj*, Mega Oktia Yoza, Jon Efendi \\ Program Studi Pendidikan Kimia Pascasarjana Universitas Negeri Padang \\ E-mail: latisma_dj@yahoo.com
}

\begin{abstract}
The purpose of this research was to describe the life skills of students in learning chemistry and reveals the connections between life skills. The methods used in this research is descriptive research. The subject of research as much as 144 students of class $\mathrm{XI}$ in one of senior high school in the city of Padang. The selection of samples was conducted with stratified random sampling technique that divides students into 3 groups based on the level of their intelligence (IQ). Research data taken with observation, interview guidelines and tests of the student's life skills. The results showed that the personal skills for students classified as well. The social skills of students is very good, students are able to manage their emotions very well, able to communicate well, has good interpersonal relationships, and understanding the other person very well. Student's academic prowess is quite good the ability of critical thinking, creative thinking, problem solving, and decision making students are on a category is good enough. The connection between life skills showed that a) there is a weak relationship between personal proficiency students with social skills among students with the values of the coefficients of correlation $0.33, \mathrm{~b}$ ) there is a very weak relationship between students personal skills with the academic skills of students with the value of the correlation coefficient 0,004 , and c) there is a very weak relationship between social skills among students with the academic skills of students with the value of the correlation coefficient 0,062 .
\end{abstract}

Key words : Life Skill, Personal Skills, Social Skills, Academic Skill

\begin{abstract}
Abstrak
Tujuan dari penelitian ini adalah untuk mendeskripsikan kecakapan hidup siswa pada pembelajaran kimia dan mengungkapkan hubungan antar kecakapan hidup. Penelitian deskriptif ini mengambil subjek penelitian sebanyak 144 orang siswa kelas XI di salah satu SMA Negeri di kota Padang. Pemilihan sampel dilakukan dengan teknik stratified random sampling, membagi siswa menjadi 3 kelompok berdasarkan tingkat kecerdasannya (IQ). Data penelitian diambil dengan pedoman observasi, pedoman wawancara dan tes uji kecakapan hidup siswa. Sumber data yang digunakan dalam penelitian ini adalah guru, siswa, dan proses pembelajaran. Hasil penelitian menunjukkan bahwa untuk kecakapan personal siswa tergolong baik. Kecakapan sosial siswa tergolong sangat baik. Kecakapan akademik siswa tergolong cukup baik. Korelasi antar kecakapan hidup menunjukkan bahwa a) terdapat hubungan yang lemah antara kecakapan personal siswa dengan kecakapan sosial siswa, b) tidak terdapat hubungan (sangat lemah) antara kecakapan personal siswa dengan kecakapan akademik, dan antara kecakapan sosial siswa dengan kecakapan akademik siswa.
\end{abstract}

Kata Kunci : Kecakapan hidup, personal, sosial, akademik 


\section{PENDAHULUAN}

Pasal 3 UU No. 20 Tahun 2003 Tentang Sistem Pendidikan Nasional menyatakan bahwa: "Pendidikan nasional berfungsi mengembangkan kemampuan dan membentuk watak serta peradaban bangsa yang bermartabat dalam rangka mencerdaskan kehidupan bangsa, bertujuan untuk berkembangnya potensi peserta didik agar menjadi manusia yang beriman dan bertakwa kepada Tuhan Yang Maha Esa, berakhlak mulia, sehat, berilmu, cakap, kreatif, mandiri, dan menjadi warga negara yang demokratis serta bertanggung jawab". Dengan kata lain, pendidikan tidak hanya membentuk insan Indonesia yang cerdas, namun juga berkepribadian atau berkarakter, sehingga nantinya akan lahir generasi bangsa yang tumbuh berkembang dengan karakter yang bernafas nilai-nilai luhur bangsa serta agama.

Salah satu upaya pembentukan karakter pada diri siswa pada pembelajaran kimia adalah dengan membekali siswa dengan kecakapan hidup. Kecakapan hidup adalah kemampuan dan keberanian untuk menghadapi problema kehidupan, kemudian secara proaktif dan kreatif mencari dan menemukan solusi untuk mengatasinya (Depdiknas, 2009). Oleh karena itu, pendidikan tidak hanya mengejar pengetahuan semata, tetapi juga pada pengembangan keterampilan, sikap, dan nilai-nilai yang dapat direfleksikan dalam kehidupan sehari-hari.

WHO (1997) mengungkapkan bahwa terdapat 10 inti kecakapan hidup yang dikelompokkan ke dalam 3 jenis kecakapan hidup yaitu kecakapan personal, sosial dan akademik. Sairo (2009) mengatakan bahwa kecakapan hidup dapat memberikan siswa keterampilan berharga yang dapat mereka gunakan dalam masyarakat yang mungkin memiliki pandangan berbeda dari diri mereka sendiri. Penelitian ini bertujuan untuk menganalisis kecakapan hidup yang dimiliki siswa setelah mengikuti pembelajaran kimia. Selain itu, penelitian ini juga bertujuan untuk mengungkapkan keterkaitan antar kecakapan hidup.

\section{METODE PENELITIAN}

Penelitian ini merupakan penelitian deskriptif yang menjelaskan suatu fenomena menggunakan angka untuk menciptakan gambaran dari sebuah kelompok atau individu (Schreiber, 2011). Pada penelitian ini, siswa dibagi atas tiga kelompok berdasarkan tingkat kecerdasan (IQ) yaitu kelompok superior yaitu siswa dengan IQ>125, kelompok 
di atas rata-rata yaitu siswa dengan IQ 111-125, dan kelompok rata-rata yaitu siswa dengan IQ 90-110 (Aedy, 2009). Adapun penentuan jumlah sampel/siswa pada penelitian ini menggunakan Tabel Krejcie (1970). Berdasarkan tabel Krejcie dapat dilihat bahwa jumlah populasi pada penelitian ini adalah 238 orang, maka jumlah sampel yang digunakan pada peneliti ini adalah 144 orang dari 7 kelas.

Instrumen yang digunakan pada penelitian ini adalah pedoman observasi, pedoman wawancara dan tes kecakapan hidup. Sumber data yang digunakan dalam penelitian ini adalah guru, siswa, dan proses pembelajaran di kelas XI IPA salah satu SMA di kota Padang. Sebelum digunakan instrument berupa tes kecakapan hidup divalidasi terlebih dahulu. Dalam penelitian ini, peneliti berperan sebagai seorang nonparticipant observer. Observasi dilakukan selama pembelajaran berlangsung. Oneon-one interviews dilakukan menggunakan structured interviews. Jenis pertanyaan yang digunakan adalah open-ended question yaitu pertanyaan yang meminta responden untuk memberikan jawaban dengan lengkap (Gay, 2009).

Tes yang digunakan berupa soal-soal yang mengandung aspek-aspek kecakapan hidup. Setiap butir soalnya dibuat berdasarkan indikator-indikator yang telah ditetapkan oleh WHO. Dengan tes tersebut, peneliti akan mengolah data hasil tes untuk mengetahui seberapa jauh pengenalan maupun penguasaan siswa terhadap aspek-aspek kecakapan hidup yang ditemukan dalam pembelajaran kimia. Analisis data menggunakan rumus Spearman Rank dengan bantuan program SPSS 16.0 for windows.

Pengujian korelasi antar kecakapan hidup dilakukan untuk memperkuat analisis data dari hasil tes kecakapan hidup siswa. Adapun langkah-langkah dalam pengujian korelasi antar kecakapan hidup yaitu :

a) Mengubah data ordinal, yang berasal dari tes kecakapan personal dan sosial, menjadi data interval dengan menggunakan Metode Suksesif Interval (MSI) dengan Microsoft Office Excel.

b) Mencari koefisien korelasi $r_{\text {hitung }}$ dengan rumus korelasi Pearson. untuk memperkuat ada atau tidaknya kaitan antar kecakapan hidup, maka perlu dicari koefisien determinasi $\left(r^{2}\right)$. 


\section{HASIL DAN PEMBAHASAN}

\section{A. HASIL}

\section{Kecakapan Personal (Personal Life Skill)}

Data mengenai Kecakapan Personal yang meliputi kesadaran diri (self Awareness) siswa dalam mengenal karakternya dan kecakapan mengelola stress diperoleh dari tes kecakapan hidup. Data nilai siswa yang mengembangkan aspek kecakapan personal ditunjukkan pada Tabel 1.

Tabel 1. Sebaran Nilai Siswa pada Setiap Kelompok Aspek Kecakapan Personal

\begin{tabular}{ccccc}
\hline Kelompok Siswa & \multicolumn{2}{c}{ Nilai rata-rata } & \multicolumn{2}{c}{ Kategori } \\
\cline { 2 - 5 } & $\begin{array}{c}\text { Kesadaran } \\
\text { diri }\end{array}$ & $\begin{array}{c}\text { Pengelolaan } \\
\text { stres }\end{array}$ & $\begin{array}{c}\text { Kesadara } \\
\text { diri }\end{array}$ & $\begin{array}{c}\text { Pengelolaan } \\
\text { stres }\end{array}$ \\
\hline superior & 77 & 66 & Baik & Baik \\
\hline Diatas rata-rata & 75 & 65 & Baik & Baik \\
\hline Rata-rata & 74 & 61 & Baik & Baik \\
\hline
\end{tabular}

Tabel 1 memperlihatkan bahwa kelompok superior memiliki kesadaran diri dan pengelolaan stress yang sedikit lebih baik dibandingkan dengan dua kelompok lainnya. Jika dilihat dari nilai masing-masing siswa, maka sebarannya dapat dilihat pada Gambar 1.

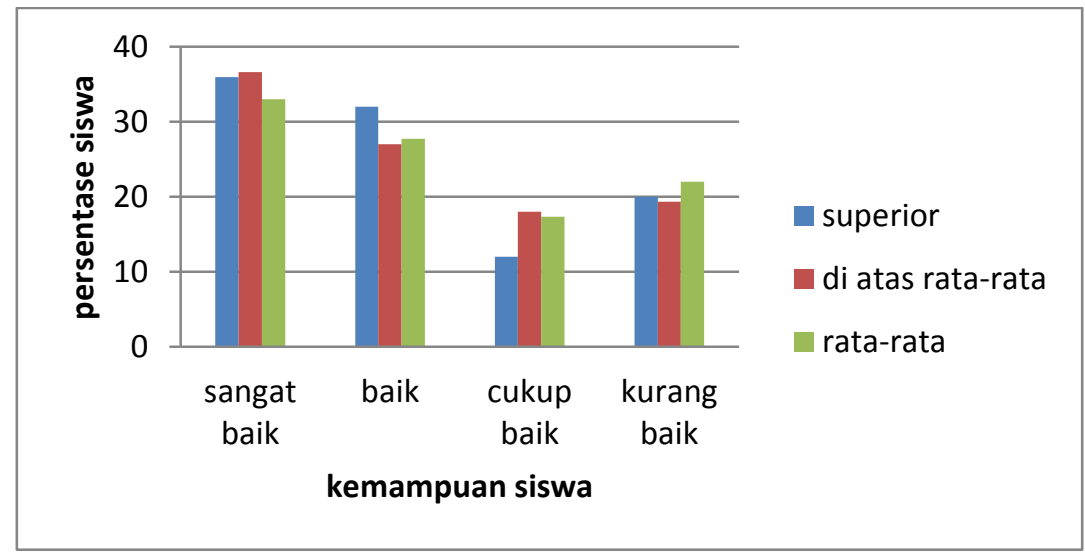

Gambar 1. Grafik Sebaran Siswa pada Aspek Kecakapan Personal Berdasarkan

Kelompok Siswa

Gambar 1 memperlihatkan bahwa kecakapan personal ketiga kelompok siswa tidak jauh berbeda. Jumlah siswa dengan kategori sangat baik untuk tiga kelompok tersebut hampir sama yaitu 36\% untuk siswa dengan kategori superior dan di atas ratarata serta $33 \%$ untuk siswa kelompok rata-rata. 


\section{Kecakapan Sosial (Social Life Skill)}

Kecakapan sosial siswa yang diteliti meliputi, pengelolaan emosi, kemampuan berkomunikasi, hubungan interpersonal, dan empati. Data yang diperoleh berupa data hasil observasi, tes kecakapan hidup, dan hasil wawancara. Nilai rata-rata siswa untuk kecakapan sosial dapat dilihat pada Tabel 2 .

Tabel 2. Sebaran nilai Siswa pada Setiap Kelompok Aspek Kecakapan Sosial

\begin{tabular}{ccccccccc}
\hline \multirow{2}{*}{$\begin{array}{c}\text { Kelompok } \\
\text { siswa }\end{array}$} & $\begin{array}{c}\text { Nengelolaan } \\
\text { emosi }\end{array}$ & Komunikasi & $\begin{array}{c}\text { Hub. } \\
\text { Inter } \\
\text { personal }\end{array}$ & impati & $\begin{array}{c}\text { Pengelolaan } \\
\text { emosi }\end{array}$ & Komunikasi & $\begin{array}{c}\text { Hub. Inter } \\
\text { personal }\end{array}$ & Empati \\
\hline superior & 87 & 80 & 75 & 88 & SB & Baik & Baik & SB \\
\hline $\begin{array}{c}\text { Diatas } \\
\text { rata-rata }\end{array}$ & 85 & 80 & 77 & 84 & SB & Baik & Baik & Baik \\
\hline Rata-rata & 85 & 80 & 79 & 87 & SB & Baik & Baik & SB \\
\hline
\end{tabular}

Jika dilihat dari nilai masing-masing siswa, maka sebarannya dapat dilihat pada Gambar 2.

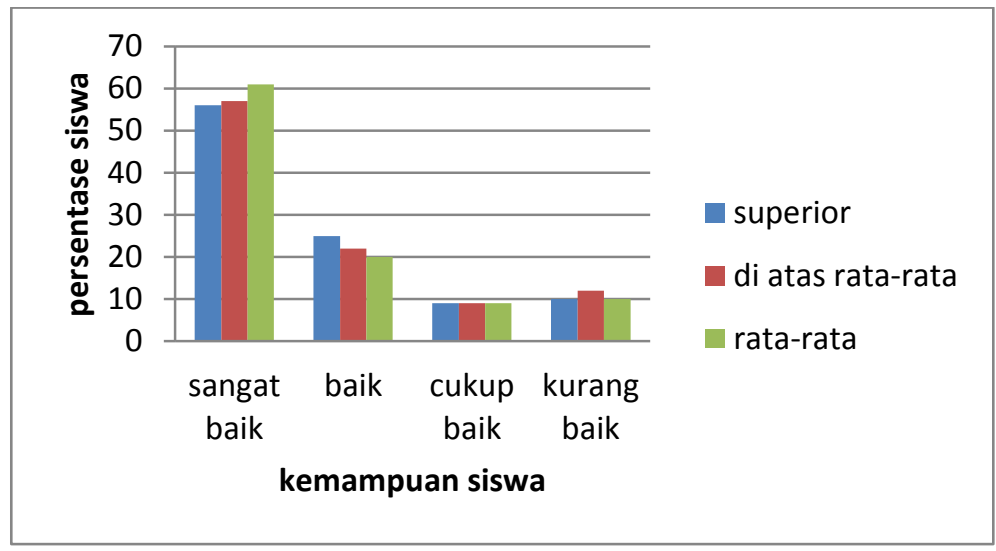

Gambar 2. Grafik Sebaran Siswa pada Aspek Kecakapan sosial

Gambar 2 memperlihatkan bahwa jumlah siswa kelompok rata-rata yang memiliki kecakapan social pada kategori sangat baik lebih banyak dibandingkan dengan dua kelompok lainnya. $61 \%$ siswa kelompok rata-rata ada pada kategori sangat baik, $56 \%$ siswa superior dan 57\% siswa di atas rata-rata, sedangkan untuk kategori baik, kurang baik dan tidak baik, ketiga kelompok siswa hampir sama.

\section{Kecakapan akademik ( Academic skills)}

Aspek kecakapan akademik yang diteliti dibatasi pada kemampuan berpikir kritis, berpikir kreatif, pemecahan masalah, dan pengambilan keputusan. Tes yang digunakan terdiri dari 12 buah soal kimia dalam bentuk essay. Berpikir kritis 
merupakan salah satu kemampuan berpikir tingkat tinggi dengan tiga aspek yaitu definisi dan klarifikasi masalah, menilai informasi yang berhubungan dengan masalah, dan memecahkan masalah atau membuat kesimpulan. Kemampuan ini diukur dengan 3 buah soal yaitu menentukan bilangan kuantum dari elektron yang dilepaskan oleh ion $\mathrm{Cu}^{+}$, menjelaskan kenapa senyawa HF memiliki titik didih lebih tinggi dibandingkan dengan senyawa $\mathrm{HCl}, \mathrm{HBr}, \mathrm{HI}$ dan pada soal nomor 7 , siswa diminta untuk menjelaskan proses eksoterm berdasarkan pencampuran dua zat.

Berpikir kreatif merupakan salah satu kemampuan berpikir tingkat tinggi dengan tiga aspek yaitu kelancaran (fluency), keluwesan (flexibility), dan keaslian (originality).Kemampuan ini juga diukur dengan 3 buah soal mengenai laju reaksi. kelompok superior sudah menguasai ketiga aspek berpikir kreatif. Selain itu, aspek berpikir kreatif yang dikuasai oleh siswa dengan baik adalah keaslian (originality). kelompok superior memiliki kemampuan berpikir baik dibandingkan dengan kelompok lainnya.

Kemampuan pemecahan masalah dilihat dari penyelesaian soal nomor 6, 10, dan 12. Siswa diminta untuk menentukan $\Delta \mathrm{H}$ pembentukan $\mathrm{Ca}(\mathrm{OH})_{2}$ menggunakan hukum Hess, kemudian siswa diminta untuk menentukan laju reaksi pada konsentrasi tertentu. Hasil pengolahan data memperlihatkan bahwa kelompok di atas rata-rata memiliki kemampuan pemecahan masalah yang baik dibandingkan dengan kelompok lainnya.

Kemampuan pengambilan keputusan diukur pada soal nomor 3, 5, dan 11. Siswa diminta untuk menentukan bentuk molekul suatu senyawa jika diketahui nomor atomnya, menentukan atom-atom yang dapat membentuk ikatan ion jika diketahui nomor atomnya, serta menentukan perlakuan yang dapat menaikkan produk jika diketahui persamaan reaksinya. Siswa kelompok superior memiliki kemampuan pengambilan keputusan yang lebih baik dibandingkan dengan kelompok lainnya meskipun baru berada pada kategori cukup.

Berdasarkan hasil tes tersebut, kemampuan berpikir kritis dan berpikir kreatif dan kemampuan pemecahan masalah siswa berada pada kategori cukup baik. Kemampuan siswa dalam pengambilan keputusan berada pada kategori cukup baik untuk siswa yang tergolong superior dan kategori kurang baik untuk kelompok di atas rata-rata dan ratarata. Hasilnya dapat dilihat pada Tabel 3. 
Tabel 3. Sebaran nilai Siswa pada Setiap Kelompok Aspek Kecakapan Akademik

\begin{tabular}{ccccccccc}
\hline & \multicolumn{4}{c}{ Nilai rata-rata } & \multicolumn{3}{c}{ Kategori } \\
\cline { 2 - 8 } $\begin{array}{c}\text { Kelompok } \\
\text { siswa }\end{array}$ & $\begin{array}{c}\text { Berpikir } \\
\text { kritis }\end{array}$ & $\begin{array}{c}\text { Berpikir } \\
\text { kreatif }\end{array}$ & $\begin{array}{c}\text { Pemecahan } \\
\text { masalah }\end{array}$ & $\begin{array}{c}\text { Pengambilan } \\
\text { keputusan }\end{array}$ & $\begin{array}{c}\text { Berpikir } \\
\text { kritis }\end{array}$ & $\begin{array}{c}\text { Berpikir } \\
\text { kreatif }\end{array}$ & $\begin{array}{c}\text { Pemecahan } \\
\text { masalah }\end{array}$ & $\begin{array}{c}\text { Pengambilan } \\
\text { keputusan }\end{array}$ \\
\hline superior & 60 & 60 & 44 & 59 & Cukup & Cukup & Cukup & cukup \\
\hline $\begin{array}{c}\text { Diatas rata- } \\
\text { rata }\end{array}$ & 47 & 57 & 45 & 39 & Cukup & Cukup & Cukup & kurang \\
\hline $\begin{array}{c}\text { Rata-rata } \\
\begin{array}{c}\text { Ratang } \\
\hline\end{array}\end{array}$ & 47 & 55 & 40 & 37 & Cukup & Cukup & Cukup & kurang \\
\hline
\end{tabular}

Semua kelompok, baik superior, di atas rata dan kelompok rata-rata belum mampu berpikir kritis, kreatif dengan baik. Begitu juga kemampuan pemecahan masalah mereka masih pada kategori cukup. Kelompok superior sudah cukup mampu mengambil keputusan, sementara kelompok diatas rata-rata dan kelompok rata-rata dapat dikatakan kurang mampu dalam mengambil keputusan.

4. Uji korelasi

Pengujian korelasi pada penelitian ini menggunakan metode korelasi Pearson. Berdasarkan hasil pengolahan data diperoleh nilai koefisien $r$ untuk korelasi kecakapan personal siswa dengan kecakapan sosial siswa adalah 0,33 dengan koefisien determinasi $11 \%$ dengan kata lain, hasil penelitian menunjukkan bahwa terdapat hubungan yang sangat lemah antara kecakapan personal dengan kecakapan sosial siswa Demikian juga terdapat hubungan yang sangat lemah antara kecakapan personal dengan kecakapan akademik Korelasi kecakapan personal siswa dengan kecakapan akademik siswa diperoleh $r=0,04$ dengan koefisien determinasi $0,16 \%$, serta korelasi kecakapan social siswa dengan kecakapan akademik diperoleh $r=0,062$ dengan koefisien determinasi $0,384 \%$

\section{B. PEMBAHASAN}

Kecakapan personal, sosial dan akademik ( yang disebut dengan kecakapan hidup) adalah pengalaman belajar yang diberikan oleh sekolah kepada siswa. Pengalaman belajar tersebut meliputi kecakapan personal ( mengenal diri dan mengelola stres), kecakapan sosial (mengelola emosi, komunikasi, hubungan interpersonal, dan empati), serta kecakapan akademik (berpikir kreatif, berpikir kritis, pemecahan masalah, dan pengambilan keputusan). Semua kecakapan tersebut dapat 
diperoleh dari proses pembelajaran.Kecakapan hidup merupakan kemampuan dan keberanian untuk menghadapi problema kehidupan, kemudian secara proaktif dan kreatif mencari dan menemukan solusi untuk mengatasinya (Depdiknas, 2009). Oleh karena itu, siswa diharapkan nantinya setelah tamat dari SMA sudah memiliki bekal pengetahuan dan keterampilan untuk menjalani kehidupan yang lebih baik.

Hasil penelitian menunjukkan semua kelompok siswa (superior, diatas rata-rata dan rata-rata) memiliki kemampuan berkomunikasi yang baik, hubungan interpersonal yang baik dan dapat memahami orang lain dengan sangat baik. Hubungan interpersonal dipengaruhi oleh kemampuan siswa dalam berkomunikasi. Ini terlihat dari hasil observasi ketika dalam proses pembelajaran guru memberikan kesempatan siswa untuk berdiskusi dengan teman sebangku dalam mengerjakan soal latihan terlihat keadaan kelas menjadi nyaman dan kondusif. Keterampilan siswa berkomunikasi dengan teman merupakan kemampuan dasar dalam membina hubungan.

Goleman (1997) mengatakan bahwa siswa yang memiliki IQ tinggi mempunyai kecenderungan bersikap tidak peduli, bersikap kritis, dan menjaga jarak dengan orang lain. Hal ini ditemukan dalam penelitian ini bahwa kelompok superior memiliki nilai rata-rata paling rendah pada aspek hubungan interpersonal dibandingkan dengan kelompok di atas rata-rata dan kelompok rata-rata. Kemampuan berpikir kritis dan kreatif serta kemampuan pemecahan masalah, siswa berada pada kategori cukup baik. Berpikir kritis dapat dipengaruhi oleh faktor emosi. Seperti yang diungkapkan oleh Ibrahim (2011) bahwa kondisi emosional yang baik dan terkendali dapat memicu siswa untuk berpikir jernih dalam memberikan alasan dan pertimbangan mendalam dalam membuat, mengevaluasi, mengambil, dan memperkuat suatu keputusan atau kesimpulan tentang masalah yang dihadapinya. Mengenai hubungan kecakapan personal dengan kecakapan akademik, pada penelitian ini hanya ada hubungan yang sangat lemah, demikian juga hubungan antara kecakapan sosial dengan kecakapan akademik juga pada kategori sangat lemah, namun kecakapan sosial dapat mempengaruhi kecakapan akademik. Ini sesuai dengan data yang diperoleh yang mana kesadaran diri siswa pada setiap kelompok tergolong baik, sedangkan pada kecakapan akademik tergolong cukup.

Kemampuan siswa dalam memecahkan soal, tidak dapat dikatakan tidak mampu memecahkan soal dengan baik. Sebagian besar siswa menjawab dengan cara yang praktis, tidak seperti yang telah diajarkan oleh guru dimana terdapat langkah-langkah 
dalam menyelesaikan soal perhitungan, seperti yang diungkapkan oleh Brookhart (2010) bahwa jika siswa sudah menguasai suatu permasalahan, maka siswa cenderung mengerjakannya tanpa memberikan alasan, tidak terlalu menggunakan kemampuan pemecahan masalahnya, dan langkah-langkah dalam penyelesaian tidak terlalu penting bagi siswa. Berdasarkan hasil tes kecakapan akademik, kemampuan pemecahan masalah siswa berada pada kategori cukup baik namun, hasil penelitian ini tidak didukung oleh hasil observasi yang mana guru selalu mengajarkan strategi menyelesaikan suatu soal atau masalah.

Berdasarkan pengolahan data pada keempat aspek kecakapan akademik, maka dapat dikatakan kecakapan akademik siswa tergolong cukup baik. Pembelajaran kimia diharapkan mampu menciptakan suasana yang terkondisikan dan memberikan latihanlatihan yang diperlukan oleh siswa berkaitan dengan permasalahan dalam kehidupan. Pembelajaran kimia dapat dilakukan dengan pemberian pengalaman langsung kepada siswa dengan memberikan latihan-latihan sehingga dapat membantu siswa untuk memperoleh pemahaman yang lebih mendalam tentang alam sekitar.Chan (2011) mengungkapkan bahwa keberhasilan siswa dalam kemampuan akademik dipengaruhi oleh peran serta guru dalam mengajarkan materi. Oleh karena itu, peran guru dalam mengajarkan kimia sangat mempengaruhi pembentukan kemampuan berpikir siswa.

Kelompok di atas rata-rata memiliki kemampuan dalam mengenal kegiatan yang disukainya dengan sangat baik dibandingkan dengan dua kelompok lainnya. Kelompok di atas rata-rata mampu mengenali minatnya dengan baik. namun dalam motivasi terhadap pembelajaran kimia masih lebih rendah dibandingkan dengan kelompok ratarata. Dari wawancara dengan siswa dan observasi selama pembelajaran ternyata motivasi belajar mereka sangat tergantung pada metode pembelajaran yang digunakan guru.

Kecakapan personal adalah kecakapan yang diperlukan bagi seseorang untuk mengenal dirinya secara utuh. Kecakapan personal siswa tergolong baik. Ini disebabkan karena pembelajaran tidak hanya transfer pengetahuan tetapi juga transfer nilai-nilai, seperti nilai-nilai keagamaan, yang mengarah pada pembentukan karakter siswa. Kecakapan sosial merupakan aspek yang diperkuat untuk menjangkau sisi kehidupan bersosialisasi dengan lingkungan keluarga, teman sebaya, juga lingkungan masyarakat sekitar. Berdasarkan analisis data, terdapat hubungan yang lemah antara kecakapan 
personal siswa dengan kecakapan sosial siswa. Setiap kelompok memiliki keunggulan dalam aspek kesadaran diri seperti kelompok superior mampu menerima kelemahan dengan sangat baik, mampu mengelola stres dengan sangat baik dibandingkan dengan dua kelompok lainnya.Ini disebabkan karena pada aspek kesadaran diri, kelompok superior mampu mengendalikan dirinya dengan sangat baik, sehingga kelompok superior juga akan mampu mengelola stresnya Walaupun demikian, kecakapan personal dapat mempengaruhi kecakapan sosial siswa.

\section{KESIMPULAN}

Berdasarkan hasil temuan dan pembahasan tentang kecakapan hidup siswa pada pembelajaran kimia, maka diperoleh kesimpulan sebagai berikut ini.

1. Kecakapan Personal

Kecakapan personal siswa tergolong baik. Setiap kelompok memiliki keunggulan dalam aspek kesadaran diri seperti kelompok superior mampu menerima kelemahan dengan sangat baik, mampu mengelola stres dengan sangat baik dibandingkan dengan dua kelompok lainnya.. Kelompok di atas rata-rata mampu mengenali bakatnya, dan kelompok rata-rata mampu mengenali karakternya dan memiliki motivasi yang baik terhadap pembelajaran.

\section{Kecakapan Sosial}

Kecakapan sosial siswa tergolong sangat baik. Kelompok superior mampu mengelola emosinya dengan sangat baik dibandingkan dengan dua kelompok lainnya. Siswa pada setiap kelompok memiliki kemampuan berkomunikasi yang baik, memiliki hubungan interpersonal yang baik Siswa memiliki hubungan interpersonal yang baik, dapat memahami orang lain dengan sangat baik.

3. Kecakapan Akademik

Kecakapan akademik siswa yaitu kemampuan berpikir kritis, kemampuan berpikir kreatif, juga kemampuan pemecahan masalah, tergolong cukup baik. Kemampuan siswa dalam pengambilan keputusan berada pada kategori cukup dan kurang.

4. Terdapat hubungan yang lemah antara kecakapan personal siswa dengan kecakapan sosial siswa. Walaupun demikian, kecakapan personal dapat mempengaruhi kecakapan sosial siswa seperti pengelolaan emosi siswa bergantung pada pengelolaan stres siswa..Terdapat hubungan yang sangat lemah antara kecakapan personal siswa dengan 
kecakapan akademik siswa. Terdapat hubungan yang sangat lemah antara kecakapan sosial siswa dengan kecakapan akademik siswa. Walaupun demikian, kecakapan sosial dapat mempengaruhi kecakapan akademik siswa, seperti pengelolaan emosi yang baik, membuat siswa berpikir jernih dalam menghadapi permasalahannya.

\section{DAFTAR PUSTAKA}

Aedy, Hasan. 2009. Karya Agung Sang Guru Sejati. Bandung: Alfabeta

Brookhart, Susan M. 2010. How To Assess Higher-Order Thinking Skills In Your Classroom. Virginia: ASCD

Chan, Raymond M, 2011. Interrelationships among Teacher Care, Students'Life Skills Development, and Academic Achievement: Implication for School Guidance Work. Asian Journal of Counselling, Vol. 18 No. 1 Hal. 63-9

Departemen Pendidikan Nasional. 2009. . Pendidikan Kecakapan Hidup. Jakarta: Departemen Pendidikan Nasional.

Fraenkel, Jack R, \& Norman E. Wallen. 2011. How To Design and Evaluate Research in Education. McGraw-Hill Higher Education: New York

Gay. L. R. Geoofrey E. Mills, and Peter Airasian. 2009. Educational Research Competencies for Analysis and Applications. New Jersey: Pearson Educatio

Goleman, Daniel. 1997. Kecerdasan Emosional. Jakarta: Gramedia Pustaka Utama

Krejcie, Robert V \& Darley W. Morgan. 1970. Determining Sample Size For Research Activity. Educational and Psychological Measurement Vol. 30 Hal. 607-610

Sairo. 2009. Summary of Life Skills for College Women and Men. Student Affairs Information and Research: UCLA Sairo

Schreiber, James B, and Kimberly Asner-Self. 2011. Educational Research. United State of America: Jhon Wiley \& Sons, Inc

WHO. 1997. Life Skill Education For Children And Adolescents In Schools. Geneva: Programme On Mental Health 